\title{
Study of the adult wheat and Aegilops resistance to Pseudomonas syringae pathovar atrofaciens
}

\author{
M Zaharieva, V Vassilev* \\ K Malkoff Institute for Plant Genetic Resources, 4122 Sadovo-Plovdiv, Bulgaria
}

(Received 4 October 1994; accepted 20 February 1995)

\begin{abstract}
Summary - The evaluation of the adult plant resistance of 28 genotypes belonging to Triticum $L$ and Aegilops $L$ to Pseudomonas syringae pathovar atrofaciens (PSA) were carried out at stage 10.1 (Large, 1954) after inoculation by the method of Vassilev and Karov (1986) in a glasshouse. The investigated genera showed a partial adult plant resistance to PSA. The proportion of genotypes susceptible to PSA at the highest concentration was larger for Triticum than for Aegilops.
\end{abstract}

Aegilops / Triticum / partial adult plant resistance / Pseudomons syringae pathovar atrofaciens

Résumé - Étude de la résistance du blé et d'Aegilops à Pseudomonas syringae pv atrofaciens au stade adulte. La résistance à Pseudomonas syringae pv atrofaciens des plantes adultes de 28 génotypes de Triticum $L$ et d'Aegilops L (au stade 10.1 Large 1954) a été étudiée après inoculation en serre (Vassilev et Karov, 1986). Les genres étudiés montrent une résistance partielle à PSA au stade adulte. La proportion de génotypes sensibles au PSA utilisé à la plus haute concentration étaient plus élevée pour Triticum que pour Aegilops.

Aegilops / Triticum / résistance partielle de la plante adulte /Pseudomonas syringae pv atrofaciens

\section{INTRODUCTION}

Basal glume rot of cereals caused by Pseudomonas syringae pathovar atrofaciens (PSA) has been widespread in Bulgaria, Germany, Russia and Ukraine in recent years (Karov and Vassilev, 1984; Chumaevskaya et al, 1985; Toben et al, 1989). The response to PSA of Aegilops species, ie resistance at the early stages up to tillering followed by susceptibility at later stage (tillering to booting) (Vassilev and Rachovska, 1985), appears to be similar to that of Triticum, Hordeum and Triticale responses to PSA (Vassilev et al, 1983). The aim of this study was to test the adult wheat and Aegilops resis-

\footnotetext{
* Correspondence and reprints
}

tance to PSA by artificial inoculation at the booting stage under glasshouse conditions.

\section{MATERIALS AND METHODS}

Table I and II list the wheat and Aegilops genotypes that were studied through inoculation with bacterial suspensions at increasing concentrations. Five to 10 plants per concentration were grown in a glasshouse and were inoculated at the booting stage (stage 9-10 of Large (1954), ie at a date for which the first ears would be visible $7-10 \mathrm{~d}$ later) by the method of Vassilev and Karov (1986). They were grown for vernalization until the tillering began, and were then transferred in pots (Vassilev, 1984). We injected $0.5 \mathrm{ml}$ bacterial suspension at various concentrations of inoculum 
(tables I and II) into the cavity formed by the sheath above the ear, taking care not to damage the latter. Various inoculum doses (from 10 to $10^{9} \mathrm{cfu} / \mathrm{ml}$ ) of bacterial culture aged $24-48 \mathrm{~h}$ were adjusted at $610 \mathrm{~nm}$ of Specol 10 (Carl Zeiss) using a calibration curve for the strain. The number of the infective particles forming colonies on a solid medium (cfu/ml) was determined by the method of serial dilution and the plate-count technique (Meynell and Meynell, 1965). Initial bacterial culture was V1 strain of PSA taken from our laboratory collection (Vassilev et al, 1991). Controls were treated with sterile distilled water. The inoculated plants were incubated in a non-air-conditioned glasshouse and kept moist by spraying with tap water.

Responses were evaluated on the days 7, 14 and 20 after inoculation following the method described earlier (Vassilev, 1984). Fives grades were used (0-4): plants without symptoms (0); plants with local necrosis only on the site of injection (1); plants with a $1 \mathrm{~mm}$ restricted spot (2); plants with $3-5 \mathrm{~mm}$ progressive lesions with yellow halo, and stripes, spots, or typical basal glume rot appeared on the ear after earing was complete (3); and plants in which the entire head was fully deformed, or died within the sheathing leaf (4). The degree of infection was calculated (Vassilev and Karov, 1986; Vassilev et al, 1990) and 3 groups of plant responses were described: $0.0-0.0$ immune (I); $0.1-50.0$ resistant (R); and $50.1-100.0$ susceptible (S). The experiments were done 3 time at different time periods.

\section{RESULTS}

In tables I and II, the effects of the PSA inoculum doses on the plant response at stage 10.1 is shown. The frequency of the bacterial infected genotypes increased with the increase of the inoculum dose. All Triticum $L$ and most of Aegilops $\mathrm{L}$ genotypes were infected at the highest dose. At this inoculum level, several Aegilops had resistant responses. Nevertheless, the Aegilops studied and the first 5 wheat cultivars retained some level of resistance up to $10^{7} \mathrm{cfu} / \mathrm{ml}$. The last 4 genotypes of Aegilops had been infected at this inoculum dose. Most of the wheat cultivars showed a resistant response at the medium inoculum level $\left(10^{5} \mathrm{cfu} / \mathrm{ml}\right)$. Ae umbellutata var typica, Ae speltoides and $A e$ squarrosa var typica responded as susceptible genotypes, after $10^{3} \mathrm{cfu} / \mathrm{ml}$. They were very close to Triticum L cultivars Vratza, Maris Huntsman and Maris Dove, which were susceptible at the same inoculum level. The ear of wheat genotypes was fully deformed by PSA, or died into a sheathing leaf. Similar types of symptoms were obtained on North Dakota wheat. None of the Aegilops studied were observed to show this destructive form of PSA infection. They had only stripes or spots on the glumes in the susceptible genotypes. North Dakota reacted in the same way as susceptible wheat at the lowest concentration of the bacterial suspension. The same symptoms were observed at lower bacterial concentrations of more susceptible genotypes. Some susceptible wheat cultivars showed a resistant response at the higher levels (Bezostay 1 at $10^{5} \mathrm{cfu} / \mathrm{ml}$ and Manitou at $10^{7} \mathrm{cfu} / \mathrm{ml}$ ). A similar response was checked for on the relatively

Table I. Behaviour of some wheat genotypes to PSA V1 in a glasshouse.

\begin{tabular}{|c|c|c|c|c|c|c|}
\hline \multirow[t]{2}{*}{ Genotype } & \multirow[t]{2}{*}{ Cultivar } & \multicolumn{5}{|c|}{ Inoculum concentration $(\mathrm{cfu} / \mathrm{ml})^{\text {a }}$} \\
\hline & & $10^{1}$ & $10^{3}$ & $10^{5}$ & $10^{7}$ & $10^{9}$ \\
\hline 11645 & Kitakami Komugi & 1 & 1 & $\mathrm{R}$ & $R$ & $S$ \\
\hline 11984 & Titan & I & $\mathrm{R}$ & $\mathrm{R}$ & $\mathrm{R}$ & $\mathrm{S}$ \\
\hline 03405 & Milling & I & $\mathrm{R}$ & $\mathrm{R}$ & I & $s$ \\
\hline 11858 & Caprok & 1 & $\mathrm{R}$ & $\mathrm{R}$ & $\mathrm{R}$ & $S$ \\
\hline 11549 & Norin 1 & I & $\mathrm{R}$ & $\mathrm{R}$ & $\mathrm{R}$ & $\mathrm{S}$ \\
\hline 11882 & Gaines & I & $\mathrm{R}$ & $\mathrm{R}$ & $S$ & $S$ \\
\hline 11995 & Val & i & $\mathrm{R}$ & $R$ & $\mathrm{~S}$ & $\mathrm{~S}$ \\
\hline 11999 & Waldron & i & $\mathrm{R}$ & $\mathrm{R}$ & $\mathrm{S}$ & $S$ \\
\hline 11682 & Bezostay 1 & 1 & $S$ & $R$ & $S$ & $S$ \\
\hline 11927 & Manitou & i & $\mathrm{S}$ & $\mathrm{S}$ & $\mathrm{R}$ & $\mathrm{S}$ \\
\hline 11726 & Vratza & I & $\mathrm{S}$ & $S$ & $S$ & $S$ \\
\hline 11539 & Maris Huntsman & i & $\mathrm{S}$ & $\mathrm{S}$ & $\mathrm{S}$ & $S$ \\
\hline 11502 & Maris Dove & i & $\mathrm{S}$ & $S$ & $\mathrm{~S}$ & $\mathrm{~S}$ \\
\hline 03347 & North Dakota & $S$ & $S$ & $S$ & $S$ & $\mathrm{~S}$ \\
\hline
\end{tabular}

a I: immune; R: resistant; S: susceptible. 
Table II. Behaviour of some Aegilops genotypes to PSA V1 in a glasshouse.

\section{Genotype Species and subspecies}

\author{
Ae squarrosa var anatera \\ Ae triuncialis var typica \\ Ae triaristata \\ Aegilops sp \\ Ae cylindrica \\ Ae ventricosa \\ Aegilops sp \\ Aegilops sp \\ Ae variabilis \\ Aegilops sp \\ Ae ovata var vulgare \\ Ae umbellutata var typica \\ Ae speltoides \\ Ae squarrosa var strangulata
}

Inoculum concentration (cfu/ml)

$10^{1}$

$\begin{array}{lll}10^{3} & 10^{5} & 10^{7}\end{array}$

$10^{9}$

I: immune: R: resistant; S: susceptible.

resistant Milling wheat between $10^{7}$ and $10^{9}$ $\mathrm{cfu} / \mathrm{ml}$. No symptoms were seen in this case.

\section{DISCUSSION}

Vassilev et al (1983) have previously reported wheat and barley as being susceptible at stage 9-10. Rye and Triticale showed resistant or moderately resistant to moderately susceptible response for the second species. In the present study, we found that the proportion of genotypes susceptible to PSA at the highest concentration was higher for Triticum than for Aegilops, and relative frequency of the infected plants increased with the increase of the inoculum level (data not presented), which confirmed the quantitative character of the plant resistance to the bacterium. Hence, the investigated genera showed a partial adult plant resistance to PSA, as most of them were susceptible at the highest inoculum dose $\left(10^{9}\right.$ $\mathrm{cfu} / \mathrm{ml}$ ). Several Aegilops genotypes responded as susceptible ones, at the lower dose $\left(10^{3} \mathrm{cfu} / \mathrm{ml}\right)$. None of the Aegilops studied had the same higher susceptibility to PSA as the North Dakota wheat.

Originally, McCulloch (1920) described a dull brownish-black area on the head of wheat at the base of glumes. Sometimes this dark area extended over nearly the whole surface of the glume, but usually only the lower third or less was darkened and often no discoloration was visible on the exterior. Frequently, a narrow dark line at the junction of the spikelet and the rachis was the only outward sign of the disease. This type of typical basal glume rot symptom has rarely been observed (Wilkie, 1973; Vassilev and Karov, 1982; Toben et al, 1989; Pasichnik and Koroleva, 1991).

In the case of similarity of stripes caused by PSA, undistinguished from those incited by Xanthomonas campestris pathovar translucens, many authors recommended bacteriological analysis (Dippenaar, 1931; Noble, 1933; Galatchyan, 1946; Karov and Vassilev, 1981). One very destructive form of damage, when the ear is fully deformed by PSA (Dippenaar, 1931; Vassilev and Karov, 1982), could be the object of a special study, since the symptoms were obtained simply by injection at 7-10 d before heading (Vassilev et al, 1990). Similar severe atypical damage (different from classical basal glume rot) was observed by Dippenaar (1931) in natural PSA infection. He speculated that injuries caused by bacteria resembled frost damage of the wheat head. Karov and Vassilev (1990) stressed that the basal glume rot symptoms were dependent on the cultivar, strain and environment factors. Most probably, at this stage of plant development, there were insect vectors or wounding factors when the plants were resistant to penetration, but very susceptible in the plant tissues. Sometimes Fusarium culmorum and PSA act mutually and have caused a huge outbreaks of this type (Vassilev and Karadzhova, 1988). Similar types of symptoms were obtained on North Dakota wheat. The same symptoms 
were also observed at a lower bacterial concentration of more susceptible genotypes. None of the Aegilops studied have shown this destructive form of PSA infection and only had stripes or spots on the glumes.

Some susceptible wheat cultivars have occasionally shown a resistant response at some higher inoculum level. When the inoculum dose was high, some hypersensitive response usually occurs (Gabova et al, 1983). This may lead to an incorrect estimation of plant response using only one inoculum level of bacterial suspension.

The methods of inoculation were of great importance for the correct test of plant resistance. In our previous experiments (Vassilev et al, 1991), at the milk stage, a bacterial suspension containing $10^{7} \mathrm{cfu} / \mathrm{ml}$ was sprayed onto heads of wheat, until small water droplets appeared on the glumes. The inoculated plants were incubated in a humidity chamber. The percentages of infected spikelets varied considerably, depending on the growth conditions. The injection method gave us the precise inoculum dosage, the certainty in the infective process, and less dependence on the environment.

\section{CONCLUSIONS}

The evaluation of the adult plant resistance of Triticum L and Aegilops L genotypes to PSA in a glasshouse was possible using the injection method at the susceptible growth stage 9-10 of both species. Symptoms resembling the natural infection allowed the correct assessment of the genotype resistance to PSA. The investigated genera showed a partial adult plant resistance to PSA. The proportion of genotypes susceptible to PSA at the highest concentration was higher for Triticum than for Aegilops.

\section{REFERENCES}

Chumaevskaya MA, Matveeva EV, Koroleva IB (1985) Bacterial Diseases of Cereal Crops. Kolos, Moscow, Russia, $288 p$

Dippenaar BJ (1931) N bacteriese siekte wat' 'n verdorring van die kaffies van koringare veroorsaak. $S$ Afr J Sci 28, 280-283

Gabova R, Vassilev V, Karov S (1983) Hypersensitivity response of wheat induced by $P$ syringae pv atrofaciens. In: Proc 2nd Nat Symp Immun Plants, VSI, Plovdiv, Bulgaria, 195-203

Galatchayan RM (1946) Bacteriosis of cereals Bact atrofaciens McCull and measures controlling it. Microbiol Medley Georgian Acad Sci 2, 65-83
Karov S, Vassilev V (1981) Studies on bacterioses of wheat in Bulgaria. I. Basal glume rot. Sci Works, VSI Plovdiv, Bulgaria, 26, 85-90

Karov S, Vassilev V (1984) Bacterioses in cereals problems and achievements. In: Proc Jubilee Scient Sess, Sadovo, Bulgaria, 387-391

Karov S, Vassilev V (1990) Bacterial diseases of Gramineae in Bulgaria. In: Proc 7th Intern Conf Plant Pathog Bact, AK, Budapest, Hungary, A, 311316

Large EC (1954) Growth stages in cereals - illustration of the Feekes scale. Plant Pathol 3, 128-129

McCulloch L (1920) Basal glume rot of wheat. J Agric Res 28, 543-551

Meynell G, Meynell E (1965) Theory and Practice in Experimental Bacteriology. Univ Press, Cambridge, UK, 347

Noble R (1933) Basal glume rot. A bacterial disease of wheat. Agric Gazette NSW 107-109

Pasichnik LA, Koroleva IB (1991) Pseudomonas syringae $\mathrm{pv}$ atrofaciens, an agent of bacterial spot of rye in the Ukraine. J Microbiol (Ua) 53, 49-55

Toben H, Mavridis A, Rudolph K (1989) Basal glume rot ( $P$ syringae $\mathrm{pv}$ atrofaciens) on wheat and barley in FRG and resistance screening of wheat. Bull OEPP/EPPO Bull 19,119-125

Vassilev $V(1984)$ Studies on basal glume rot of cereals and the wheat resistance to its. PhD Dissertation, Univ Agric, Plovdiv, Bulgaria, 33-44

Vassilev V, Karov S (1982) External symptoms of wheat basal glume rot in Bulgaria. Plant Sci 19, 99-106

Vassilev V, Rachovska G (1985) Responses of different Aegilops after artificial inoculation by agent of basal glume rot of cereals. In: Proc 13th Republican Symp Young Sci CINTI, Sofia, Bulgaria, 1, 184-188

Vassilev V, Karov S (1986) Methods of artificial inoculation and evaluation of wheat resistance to $P$ syringae pv atrofaciens. Soil Sci Agrochem Plant Protec 1, 92-99

Vassilev V, Karadzhova J (1988) A mixed infection of Fusarium culmorum and $P$ syringae $\mathrm{pv}$ atrofaciens in winter soft wheat. Plant Sci 25, 91-94

Vassilev V, Karov S, Matzov B, Perfanov K (1983) Responses of cereals artificially inoculated with $P$ syringae pv atrofaciens in different stages of development. In: Proc 2nd Nat Symp Immun Plants, VSI, Plovdiv, Bulgaria, 205-213

Vassilev V, Milanova M, Karov S (1990) Methods of inoculation and evaluation of quantitative wheat resistance to facultative pathogenic microorganisms in the ear. In: Proc Intern Wheat Symp, Univ Press, Varna, Bulgaria, 327-330

Vassilev V, Von Kietzell J, Toben H, Mavridis A, Rudolph K (1991) Studies on wheat - Pseudomonas syringae interactions. In: Proc 4th Intern Work Group on P syringae Pathovars, Stamperia Granducale, Florence, Italy, 109-116

Wilkie JP (1973) Basal glume rot of wheat in New Zealand. $N Z J$ Agric Res 16, 155-160 